\title{
Patronage politics as a driver of economic regionalisation: The Indonesian oil palm sector and transboundary haze
}

\section{By HELENA VARKKEY}

\begin{abstract}
Recent evidence has linked illegal peat and forest fires in Indonesia to commercial oil palm plantations. Fire is the most cost-efficient way to clear land for planting, but these fires release smoke causing transboundary haze pollution. The countries worst affected by the haze are neighbouring Malaysia and Singapore. Malaysian and Singaporean investors control more than two-thirds of the Indonesian oil palm plantation sector and they have been implicated in the fires alongside local plantations. Using information obtained from interviews with individuals linked to the sector, this paper aims to explain why these companies continue to burn despite the dire consequences of the haze. It identifies patronage politics as a common business culture in Southeast Asia, and argues that because these Malaysian and Singaporean investors are already familiar with patronage practices at home, they have easily inserted themselves into existing patronage networks in Indonesia. Hence, these companies enjoy the protection of their Indonesian patrons during their operations. Furthermore, in a business atmosphere defined by patronage politics, clients are largely motivated by material gain. This explains why Malaysian and Singaporean investors continue to clear land by fire in the interests of cost-efficiency, despite their home countries suffering the worst effects of haze.
\end{abstract}

Keywords: economic regionalisation, Indonesia, oil palm, patronage politics, Southeast Asia, transboundary haze 


\section{Patronage Politics as a Driver of Economic Regionalization in Indonesia: The Oil Palm Sector and Haze}

\section{Introduction}

The Indonesian archipelago consists of 18,110 islands with a total land area of $1,890,754$ hectares, with tropical climate and high rainfall. These geographical conditions make Indonesia a highly biologically affluent country, with huge agricultural potential (Widianarko, 2009: 2). Indonesia's favorable climate and good soil conditions make it especially suitable for the cultivation of oil palm (Samsul et al., 2007: 1, Butler et al., 2009: 68). These conditions support the growth of high yield oil palms (3,511 kilolitres per hectare) which could be harvested throughout the year, resulting in a palm oil production process that is highly efficient (Suharto, 2011: 19).

\section{Figure 1: Area harvested of oil palm fruit in Indonesia, 1961-2009}

Interest in oil palm cultivation in Indonesia began during the colonial times, when Dutch settlers planted the first four African palms in Buitenzorg Botanical Garden (now Bogor) (Wahid et al., 2004: 3). The lucrative economic returns from palm oil in neighbouring Malaysia (which was an early mover for palm oil) encouraged Indonesia to expand its oil palm cultivation (Basiron, 2007: 291). Indonesia started rapidly opening up oil palm plantations in Sumatra and Kalimantan in the 1980s (see Figure 1) (Indonesian Government, 1998), fuelled by a specific policy goal that was formulated by the Indonesian government to overthrow Malaysia as the world's largest palm oil producer (Van Gelder, 2004: 19). Expansion was pursued largely through the privatization of previously state-run estates, particularly through the 'Estate Transmigration Programme' and the 
'Plantation Revitalization Programme' known collectively by its Indonesian acronym PIR-Trans (McCarthy and Cramb, 2009: 114-117, McCarthy, 2010: 822-844, Casson, 2002: 221-242).

\section{Figure 2: CPO production by country}

Consequently in Indonesia, large commercial plantations began to shift from logging and pulp and paper production to oil palm production (McCarthy and Zen, 2010: 155-156). These included major conglomerates like Bakrie Sumatra Plantations (BSP), Duta Palma, Astra Agro, Makin Group, and Musim Mas (Van Gelder, 2004: 32). By 2008, Indonesia overtook Malaysia to become the world's biggest producer of palm oil (McCarthy, 2010: 822-844, Jarvis et al., 2010-12, Reuters, 2011, World Growth, 2011-13, Bernama, 2010), producing over 25 million tonnes of palm oil annually (Interviewee I48, 2011) and contributing to about $51 \%$ of world production (see Figure 2) (Di, 2011: 3). In terms of revenue, the sector contributes around 5\% of Indonesia's GDP annually (see Figure 3) (iStockAnalyst, 2009).

\section{Figure 3: Breakdown of Indonesia's 2010 GDP by sector}

However, this rapid expansion of the oil palm plantation sector in Indonesia was not entirely homegrown. To further encourage growth of the sector, Indonesia opened up its oil palm sector to foreign investors during the early 1990s (McCarthy and Cramb, 2009: 114-117). A trend quickly developed within the sector where regional investors, Malaysian and Singaporean investors in particular, overwhelmingly outnumbered investors from other countries (see Figure 4) (Marinova, 1999: 77). Currently Malaysian and Singaporean investments hold more than twothirds of Indonesia's total oil palm plantation area (WALHI et al., 2009: 228-243).

\section{Figure 4: Country of origin of investors in the oil palm sector in Indonesia, 2004}


A better understanding of investment trends and motivations within the Indonesian oil palm plantation sector is pertinent in the face of recent increased evidence of the link between illegal peat and forest fires and commercial oil palm plantations (Sawit Watch, 2007: 1, WALHI et al., 2009). Hotspot maps superimposed over concession maps suggest that many large plantation companies were systematically setting fire to both peatlands and other areas for land clearing (Chiew [M15], 2010, Ramakrishna [M20], 2010, Arif [I41], 2011). Based on satellite data, it is estimated that $80 \%$ of the fires were set by plantation companies or their sub-contractors for land clearing purposes, while the remaining 20\% were set by slash-and-burn farmers (Tan [S7], 2010, Rukmantara [I45], 2011). Such open burning is the most cost-effective method to clear land to flatten the stumps left over from logging and old crops, as well as to clear smaller vegetation in preparation for planting (Interviewee I49, 2011: 13-17, Dauvergne, 1998).

These fires release smoke, which, when in sufficient amounts to travel across boundaries, result in what is known as transboundary haze pollution (Tan et al., 2009: 423). The almost annual haze affects the health of some 75 million people and the economies of six Southeast Asian nations; with the worst affected being Malaysia and Singapore (Mayer, 2006: 202-203). With Malaysian and Singaporean plantation investors implicated in causing fires alongside local Indonesian plantation firms, the involvement of Malaysian and Singaporean firms in this sector, especially since their practices directly victimize their home countries, become of great concern. Therefore, with a close analysis of foreign investment trends and business practices in the sector, this paper aims to contribute to the larger understanding on why these commercial plantations in Indonesia have been able to carry out these illegal burning activities with such impunity. Such an understanding is pertinent in finding solutions to mitigate the recurring problem of transboundary haze in the region. 


\section{Conceptual framework}

This paper uses the concept of economic regionalization to explain the trend of Malaysian and Singaporean plantation investors in Indonesia. Economic regionalization refers to 'often undirected processes of integration that arise from markets, private trade and investment flows, and the policies and decisions of companies' (Breslin and Higgott, 2003: 177). It involves autonomous economic processes which lead to comparably higher levels of economic interdependence within a given geographical area. This includes the growth of intra-firm trade, the increasing numbers of international mergers and acquisitions, and the emergence of increasingly dense networks of strategic alliances between firms (Hurrell, 1995: 334). The concentration of Malaysian and Singaporean plantation interests in the neighbouring Indonesia is indicative of high levels of economic regionalization of the Southeast Asian oil palm plantation sector.

In the Southeast Asian context, Sim (2006: 490-491) has noted two distinct drivers of economic regionalization: the role of the state as facilitator, and the role of cultural familiarity. The role of the state as facilitator for economic regionalization in Southeast Asia has been well explored in the literature (Beeson, 2004, Scott, 1972, Sim, 2006, Breslin and Higgott, 2003, Pempel, 2005). The importance of facilitation by home (Malaysia or Singapore) and host (Indonesia) states in the economic regionalization of the Southeast Asian oil palm plantation sector has also been previously discussed elsewhere (Rajenthran, 2002, McCarthy and Cramb, 2009, Marinova, 1999, Casson, 2002, Lipsey and Sjoholm, 2011).

However, knowledge on the second driver of economic regionalization, the role of cultural familiarity, in the economic regionalization of the Southeast Asian oil palm plantation sector is 
far less clear. It has been established in the literature that a firm's initial entry is usually to a foreign market that is closer in terms of culture, including factors like language, education, business practices, and industrial development (Sim, 2006: 490). Familiarity with cultures within the same region lowers transaction costs associated with doing business. Similar cultural attitudes and heritage further fosters the development of trust and cooperative behaviour between locals and foreign investors (Terjesen and Elam, 2009: 1105-1106). This paper identifies patronage politics as common business culture among Southeast Asian states, and argues that this has been an important driver of economic regionalization in the Southeast Asian oil palm plantation sector.

Patronage politics can be defined as 'a special case of dyadic (two-person) ties involving an instrumental friendship in which an individual of higher socioeconomic position (patron) uses his own influence and resources to provide protection or benefits, or both, for a person of lower status (client) who, for his part, reciprocates by offering general support and assistance, including personal services, to the patron' (Scott, 1972: 92). Patrons and clients are exclusively motivated by material gain (Kurer, 1996: 645-661). In this way, patronage politics can be seen as 'a form of domination that is used by modern political and economic elites to channel resources for their own benefit' (Gunes-Ayata, 1994: 17-26).

While foreign firms that intend to enter into markets where patronage politics plays an important role will often attempt to engage in similar practices as well (Enderwick, 2005: 126, HamiltonHart, 2005: 171), patronage networks are more easily built and managed across similar ethnic, cultural and linguistic boundaries (Terjesen and Elam, 2009: 1105-1106). This is because internationalizing businesses tend to acquire characteristics and strategies that reflect the cultural and institutional contexts in which they are established (Hamilton-Hart, 2005: 171). Indeed, 
studies have shown that corporate firms that regionalize or internationalize often continue to display distinctive local features of their home country in their business dealings in the new host country (Doremus et al., 1999). Therefore, this paper argues that Malaysian and Singaporean plantation companies had an advantage over other foreign firms when investing in Indonesia, because of their cultural similarities with each other, especially in terms of the culture of patronage in business practices. Hence, this has been an important driver for regionalization in the Southeast Asian oil palm sector (Lawrence [I38], 2011, Anshari [I42], 2011).

Therefore, this paper argues that because these Malaysian and Singaporean firms are already familiar with patronage practices at home, Malaysian and Singaporean plantation investors were able to easily insert themselves into patronage networks in Indonesia (Tarigan [I23], 2010), further spurring economic regionalization in the sector. Although the importance of the shared culture of patronage politics within the region as a possible driver for economic regionalization in the Southeast Asian oil palm plantation sector has been previously alluded to in the literature (Gilbert, 2009, Colfer, 2002), convergent evidence on the effect of shared patronage cultures on the regionalization of Malaysian and Singaporean plantation interests to Indonesia does not yet exist.

Furthermore, while the literature has shown that patronage politics is a dominant characteristic of the societies in Southeast Asia (Enderwick, 2005: 117-127), very rarely has foreign investors been included in this analysis. Specifically, few, if any studies have examined what this paper calls the 'regionalization' of patronage politics. While traditional patronage politics has generally been characterized by highly affectionate ties based on kinship, village or neighbourhood bonds based on loyalty, obligation, honour, and non-material rewards, Dauvergne (1995) argued that the spread of market capitalism, which included the opening up of markets to foreign investment, 
has caused modern patronage exchanges to became more monetized, no longer relying on longstanding kinship bonds (Dauvergne, 1997: 75-76). This thesis adopts and extends Dauvergne's concept in the context of Malaysian and Singaporean plantation firms in Indonesia. Since patronage relations were no longer based on long-term loyalty, these 'newcomer' firms from Malaysia and Singapore were able to also easily establish their own patronage relations with Indonesian elites. Therefore, culturally-similar Malaysian and Singaporean firms were not at a disadvantage for being foreign, and were able to insert themselves into these local patronage networks. Such social ties to key 'others' of high status or with valuable knowledge, money, and relationships can provide gains through knowledge and access to local markets, distribution systems, connections around local bureaucracy and business systems, as well as potential business partners, associates and financing (Terjesen and Elam, 2009: 1105-1106).

\section{Methodology}

This research paper aims to address these gaps in the literature by providing qualitative evidence from interviews conducted among 138 individuals that are closely linked to the Indonesian oil palm plantation sector. These included government officials, journalists, non-governmental organization (NGO) representatives, former plantation staff, and academicians in Indonesia, Malaysia and Singapore. These in-depth semi-structured interviews were conducted over a period of six months in the year 2010, three months in 2011 and another three months in 2012, under approval of the Human Research Ethics Committee of the University of Sydney. These interviews were conducted as part of a larger and still ongoing study of the effect of patronage politics on regional level transboundary haze mitigation efforts. 
The interview method was especially appropriate for exploring this sensitive topic of patronage (Gill et al., 2008: 292) as it allows for easier expression of non-conformity (Stokes and Bergin, 2006: 28). However, while some interviewees allowed me to use their real names for this research, some preferred to remain anonymous. Therefore, I devised a system to maintain uniformity in the classification of interview sources for this paper. To indicate the country or institution where the interview was conducted, the letters 'I' for Indonesia, 'M' for Malaysia, and ' $\mathrm{S}$ ' for Singapore is used, along with a number to indicate the order of which the interview was conducted. For example, an interviewee who allowed himself or herself to be named, who was the tenth to be interviewed in Singapore, would appear referenced as, 'Ali [S10]'. An anonymous interviewee in Malaysia would be referenced as 'Interviewee M5'.

This paper uses the qualitative data obtained through these interviews firstly as evidence to establish the existence of the dense patronage networks that already exist between the major Indonesian oil palm plantation companies and the Indonesian government at the central and local level. It then continues to use evidence uncovered through interviews to demonstrate that Malaysian and Singaporean firms have also been able to cultivate these patronage networks among the same Indonesian political elite. This paper then discusses the implications of these networks the shaping of land policies, and law enforcement within in the Indonesian oil palm plantation sector, with specific reference to fires and haze.

\section{Patronage politics and Indonesian plantation firms}

A central feature of the Indonesian oil palm sector is the importance of patronage networks (Surya [I9] and Akbar [I10], 2010, Arif [I41], 2011, Syaf [I27], 2010, Rukmantara [I45], 2011), especially in terms of knowledge and access to local markets, distribution systems, connections 
around local bureaucracy and business systems, as well as potential business partners and associates and financing (Terjesen and Elam, 2009: 1105-1106). This sector tends to be organized through personal and industry-based social networks and relationships (Sim, 2006: 491). With the particularly long time frames of the sector (with a crop rotation of about 20 to 30 years) firms often need to cultivate long term patronage relationships throughout this period (Surya [19] and Akbar [I10], 2010).

Therefore, it is common among the top tiers of Indonesian plantation firms to have 'functional directors' appointed to perform 'extra-economic functions' (Gomez, 2009: 10), and 'advisors' who are elected on a retainer basis. Indonesia adopts a two-tier management structure, comprising a board of directors and a board of commissioners. Officially, the former manages and represents the company and the latter supervises the directors (Rajenthran, 2002: 21). However, in reality, members of the board of commissioners (and sometimes also board of directors) are typically retired senior bureaucrats (mantan) who could act as intermediaries with the state and perform 'advisory and brokerage functions' on behalf of the company when needed (Surya [19] and Akbar [I10], 2010, Syaf [I27], 2010, Arif [I41], 2011, Tarigan [I23], 2010, Anshari [I42], 2011). In other words, they are elected to the post by virtue of their connections. Indeed, for a former senior government or military official, holding such a post by virtue of their former position is usually the 'ultimate goal' after retirement, and often even while these officials are in office, they will be maintaining relationships with companies in the hopes of securing such a post after retirement (Rukmantara [I45], 2011, Syaf [I27], 2010, Syarif [I2], 2010). As one interviewee observed, "why otherwise would they put former important government people, with little or no business expertise in the sector, in their management?' (Arif [I41], 2011). 
This is an important element in patronage politics (Johnston, 2005: 21), and especially common in the oil palm sector (Surya [I9] and Akbar [I10], 2010, Arif [I41], 2011, Syaf [I27], 2010, Rukmantara [I45], 2011). For example, one of the directors of the Indonesian plantation company, BSP is Bungaran Saragih, who formerly served as Minister of Agriculture under two Indonesian cabinets. A former Minister of Agriculture, Dr. Anton Apriyantono, is also a commissioner for BSP (Bakrie Brothers, 2010). Also, Chairman of the Bakrie and Brothers Group, parent company of BSP, is Aburizal Bakrie, who is also the Chairman of the strongest and most influential political party in Indonesia, Golkar (Golongan Karyawan or the Party of the Functional Groups) (Syarif [I2], 2010, Yansen [I43], 2011). Aburizal Bakrie is known for his close relationship with Ginandjar Kartasasmita, an Indonesian politician and former speaker of the Dewan Perwakilan Rakyat Daerah (DPRD, or Regional House of Representatives). He was also a former secretary general of the Indonesian President's Economic and Financial Resilience Council (Eklof, 2002: 235). In the case of the Indonesian plantation company Duta Palma, a 30\% ownership by the Indonesian military has meant that many prominent former military men have positions within the company (Gilbert, 2009: 2-3). For example, a director at Duta Palma is a staff of the Special Presidential Division of Social Communication, retired Major General Sardan Marbun (Arif [I41], 2011).

Such appointments also occur at the local level, especially with the advent of decentralization in Indonesia. With decentralization, the role of local police chiefs (Interviewee M45 et al., 2012), local (district and regency) governments, administrators and politicians became increasingly important (Interviewee I49, 2011, Lawrence [I38], 2011). This paper therefore argues that decentralization processes have simply shifted some of the incentives and opportunities for patronage and corruption from the central to the sub-national level (Lee [S20], 2010), where 
revenue-oriented local officials and elites take advantage of decentralization by establishing local fiefdoms fed by decentralized corruption (Widianarko, 2009: 1, Syarif and Wibisana, 2007: 31). Here, high-level local politicians can use their influence to collect kickbacks from private firms (Rose-Ackerman, 2008: 331). In these ways, decentralization impedes coordination (Samsul et al., 2007: 13) and exacerbates incentives for officials at different levels to 'overgraze' the common resource base, creating new networks of patronage. Indeed, a larger number of administrative or government tiers is correlated with higher corruption and patronage (Fan et al., 2009: 14-32). With poor supervision of local politicians and bureaucrats especially after decentralization, these officials cease to be beholden to abstract rules and regulations. Rather, their actions are guided by bargaining and deals between implementers, other state officials, and strongmen outside the state (Kurer, 1996: 645-661). This situation was acknowledged by an Indonesian official at a national forum for investors and local officials, who admitted that 'doing business out of Jakarta required a firm and committed relationship with the Bupatis (head of regencies)' (Lawrence [I38], 2011).

Indeed, an interviewee from a major plantation company described these local strongmen 'like kings, who can make your life miserable if you do not have a good relationship with them' (Interviewee M45 et al., 2012). It has been documented that commercial interests which previously only cultivated patronage relationships with central government officials were now forging patronage networks with local level leaders and officials as well (Lew [M6] and Interviewee M7, 2010, Tan, 2004). Plantation companies began to elect as part of their staff local strongmen, their relatives (Surya [I9] and Akbar [I10], 2010, Wibisino [I44], 2011), retired threeor four-star Generals, police chiefs or relevant ministry staff. These individuals would be hired as managers, special 'community relations officers' (Hubungan Masyarakat or HuMas) (Peters 
[I1], 2010) or 'government relations officers' (Rowland [I39], 2011) to cultivate healthy patronage links at the local level (Peters [I1], 2010, Rukmantara [I45], 2011, Wibisino [I44], 2011). For example, an interviewee who has many years experience working in the natural resources sectors in Papua, Indonesia professed that he was in high demand among companies because of his close personal friendships to ministers and Bupatis (Rolland [I50], 2011).

\section{The 'regionalization' of patronage politics}

By virtue of being local, these local firms often also have 'home court advantages' in terms of knowledge of laws and regulations and relationships with local players including customers, governments, and other businesses. To compete in these markets, foreign firms must possess and leverage information-based tangibles (Terjesen and Elam, 2009: 1105-1106) like knowledge of local business norms and practices. This paper argues that these Malaysian and Singaporean firms, familiar with the function of patronage networks at home and possessing cultural similarities with the Indonesian host state, understood the necessity of these connections (Ghani [S6], 2010, Syarif [I2], 2010, Tarigan [I23], 2010, Wiryono [I40], 2011, Anshari [I42], 2011, Interviewee I49, 2011) and had no qualms about adopting this patronage culture themselves.

Major Malaysian investors in the Indonesian oil palm plantation industry include: Sime Darby, Tabung Haji Plantations (THP), Kuala Lumpur Kepong (KLK), Genting Plantations, and IOI Corporation (IOI). Sime Darby and THP are prominent Malaysian government-linked companies (GLCs), while Genting Plantations, KLK and IOI are owned by powerful and well-connected Chinese-Malaysian tycoons. Four of these companies are in the top 50 list of largest companies in Malaysia; Sime Darby at $7^{\text {th }}$ place, Genting at $9^{\text {th }}$, KLK at $20^{\text {th }}$ and IOI at $50^{\text {th }}$ (Gomez, 2009:375-377). All these companies are known to have close patronage relationships with their 
governments back home. This familiarity with patronage relationships, as this paper argues, has been instrumental in their successful integration within the oil palm plantation sector in Indonesia.

For example, Sime Darby cultivated a close relationship with the Malaysian government over the years as Sime Darby assisted the Malaysian government in their developmental goals, by supporting 'national causes' through the undertaking of economically risky but strategically attractive projects (Tay, 2003: 51-53). For instance, when the Sarawak Land Development Board (SLDB), the government agency that was put in charge of plantation development in Sarawak, was making substantial losses and carried major liabilities in 1987, Sime Darby stepped in to assist the state government by buying over the management of SLDB and all its plantation assets, including over 24,000 hectares of oil palm in 13 estates (McCarthy and Cramb, 2009: 113-119). This relationship has been said to render Sime Darby 'almost untouchable'. For example, interviewees who were in close contact with Malaysian NGOs related a conversation they had with officials from the Human Rights Commission of Malaysia in reference to Sime Darby. These officials told them that 'it is very difficult for us to discuss Sime Darby's actions, because the government is so involved with them'. Another prominent Malaysian GLC operating in Indonesia is THP (Surya [19] and Akbar [110], 2010). A notable director is Dato' Noordin bin Md Noor, who has been active in the Malaysian political scene since 1976, holding various important positions in the Malaysian ruling party's United Malay National Organization youth wing (TH Plantations, 2010).

Even the non-GLC Malaysian companies operating in Indonesia enjoy close connections with the Malaysian government. These companies are usually headed by elite Chinese Malaysians, who rose to prominence through sub-contracting of government contracts from powerful Malays 
in an 'Ali-Baba' arrangement where the Malay 'Ali' receives the contract through connections, then subcontracts it to the Chinese 'Baba' (Naguib and Smucker, 2009: 100-110, Norhashim and Ab. Aziz, 2005:31-45). These Chinese Malaysians eventually built up their own connections themselves among the Malay elite, and built their companies into major Malaysian conglomerates with prominent Malay and Chinese directors. For example, on the board of KLK sits Tan Sri Dato' Thong Yaw Hong, the former Secretary General of the Malaysian Treasury and later Chairman of the Employee Provident Fund (Kuala Lumpur Kepong Berhad, 2010). The EPF also holds a $12.2 \%$ stake in the company (UOB Kay Hian, 2011: 40). Another example is the board of IOI, which includes Datuk Hj Mohd Khalil B Dato' Hj Mohd Noor (a Malay), formerly the Secretary of the government's Foreign Investment Committee of Malaysia (IOI Group, 2011). Yet another example is the Board of Directors of Genting Plantations, which is populated by many Malay former military officers like retired Lt. Gen. Dato' Haji Abdul Jamil bin Haji Ahmad; retired Gen. Tan Sri Mohd Zahidi bin Hj Zainuddin; and retired Lt. Gen. Dato' Abdul Ghani bin Abdullah. Another director, Tan Sri Mohd Amin bin Osman was formerly the Director of the Malaysian Police Special Branch (Genting Plantations Berhad, 2010).

Singapore's home-grown Wilmar International is the largest palm oil producer in the world and an important player in the Indonesian oil palm plantation sector (Creagh and Chatterjee, 2010, Grant, 2008). On Wilmar's board of directors sit Chua Phuay Hee, a former senior figure in the Monetary Authority of Singapore and Yeo Teng Yang who was also a senior officer at the Monetary Authority of Singapore and Ministry of Finance, as well as Ambassador of Singapore to the European Community. Other notable figures on Wilmar's board are Leong Horn Kee and Kuok Khoon Ean. Leong served on the Singaporean Parliament for 22 years, was formerly a senior figure with the Ministry of Trade and Industry and the Ministry of Finance, and is 
currently Singapore's Non-resident Ambassador to Mexico. Kuok in turn served on various government-run statutory bodies like the Sentosa Development Corporation, The Singapore Trade Development Board, the Singapore Tourism Board, and the Singapore Management University (Wilmar, 2010).

Two other major Singapore-listed plantation companies with significant land banks in Indonesia are Golden-Agri Resources (GAR) and Indo Agri. These companies are actually subsidiaries of Indonesian-owned conglomerates Sinar Mas and The Salim Group respectively. These conglomerates shifted some of their operations and funds to Singapore in the aftermath of the Asian Financial Crisis (Rahim, 2009: 167), taking advantage of Singapore's removal of the $40 \%$ foreign ownership limit for investments in 1999 (Haggard and Low, 2002: 315). Such companies are a good reflection of the regionalization of the palm oil sector in Southeast Asia, where plantation companies cannot be easily identified with a specific national home base. These companies have appointed second-generation family members to lead these subsidiaries, alongside prominent local Singaporean directors (Rukmantara [I45], 2011, Carney and Dieleman, 2011: 116). Indo Agri's Chairman is Edward Kee Kwong Foo, a veteran of the Singapore Administrative Service who served, among other positions, as Singaporean Ambassador to Indonesia during which he received Indonesia's highest civilian honour, the Bintang Jasa Utama (First Class). On its board also sits Lim Hock San, a former senior official at the Port of Singapore Authority and the Civil Aviation Authority Singapore (Indo Food Agri Resources, 2010). And on GAR's board sits Lew Syn Pau, who served as a member of the Singaporean Parliament for 13 years, as a representative of the ruling party (Golden AgriResources Ltd, 2010). 
Interviewees opined that because of this familiarity with the function of patronage networks back home, Malaysian and Singaporean firms were more likely to engage in patronage as compared to other foreign firms operating in the Indonesian oil palm plantation sector, due to institutional inertia from behaviour in their home countries (because these companies were more likely to have engaged in patronage behaviour in their home states too) (Rolland [I50], 2011, Interviewee I49, 2011). For example, one interviewee explained that there was a marked increase of patronage behaviour from the plantation PT Asiatic Persada when it was bought over by Singapore's Wilmar from Cargill, an American company, three years ago (Interviewee I47, 2011). Cultural similarities encouraged these Malaysian and Singaporean firms to also establish their own linkages with patrons by hiring or establishing relationships with prominent Indonesians (Surya [I9] and Akbar [I10], 2010, Wibisino [I44], 2011) to leverage these tangibles. These locals are then able to use their influence over politicians and the administration to ensure preferable outcomes for these foreign companies, in the same way that Indonesian companies do (Norhashim and Ab. Aziz, 2005: 31-45).

For example, the Singapore-listed GAR is known to have several important current and former government officials (Syarif [I2], 2010, Tarigan [I23], 2010) and other prominent individuals 'on the payroll' (Dieleman and Sachs, 2006: 528-530, Dieleman and Sachs, 2008b: 278-279, Dieleman, 2010: 489, Dieleman and Sachs, 2008a: 166-167, Pratono, 2009). GAR employed Ambassador Cameron Hume (Keen, 2010), a former well-received United States ambassador to Indonesia as an advisor (Rukmantara [I45], 2011). Also, on the board of GAR's subsidiaries include Rachmad Gobel, who enjoys direct access to the President as an advisor on the National Innovation Committee; Dr Susiyati B. Hirwan, a former Director General at the State Finance Department (SMART Agribusiness and Food, 2010); and also a former senior staff of the 
Ministry of Agriculture (Tarigan [I23], 2010). Also, several NGOs that were interviewed told of the rumour that Agus Purnomo, the Indonesian Special Advisor to the Ministry of Environment and Head of the Secretariat of the National Climate Change (hence making him a central figure on conservation and sustainability issues in Indonesia) (Syarif [I2], 2010) is being employed on a retainer basis by GAR (Surya [I9] and Akbar [I10], 2010). Anthony Salim, who helms The Salim Group (the parent company for Singapore's Indo Agri) also enjoys close relations with the ruling government, having also held the position as secretary general of the President's Economic and Financial Resilience Council, before Aburizal Bakrie (Eklof, 2002: 235) as discussed above.

Other examples are the Malaysian plantation firm Sime Darby, which as a matter of principle, seeks out eminent people in host countries to be a part of its board of directors. The rationale for this is that these eminent people can further vouch for more strategically important people on the ground that Sime Darby can have strategic alliances with (Haji Mat Zin, 1999:483-484). For example, Sime Darby hired as an advisor the former Environment Minister Emil Salim (no relation to The Salim Group), who famously promoted the idea that 'nature is purely something to be exploited' during his time in office (Jakarta Post, 1987). Sime Darby also recently appointed the powerful Governor of the Indonesian Central Bank, Arifin Siregar as a commissioner (Tarigan [I23], 2010).

GAR has been known to be particularly active in recruiting instrumental individuals at the local level. For example, GAR has funded political campaigns of hopefuls and keep them on staff on a retainer basis once they have been elected to the DPRD (Syaf [I27], 2010). This creates the 'mutual hostage' situation (Interviewee I49, 2011, Yansen [I43], 2011, Tarigan [I23], 2010) where there is a mutual indebtedness between the parties, a common criteria of patronage relations (Enderwick, 2005: 129). For example, GAR has under its employment three members 
of the DPRD in Tanjung Jabung Barat in Jambi where GAR has substantial land holdings. Slamet Riyanto, a former senior staff at the Jambi provincial forestry and plantation office (Jakarta Post, 2006), was employed by GAR, and later was elected a member of the DPRD. A member of the Prosperity Justice Party (Partai Keadilan Sejahtera), Aziz Rahman, was also a staff at a GAR subsidiary and was given leave while serving as a member of the DPRD. Megawati Sihotang, a member of the Indonesian Democratic Party (Partai Demokrasi Indonesia) and DPRD representative, was also a staff of a GAR subsidiary (Syaf [I27], 2010).

This arrangement has proven beneficial for Malaysian and Singaporean firms, as well as their host country Indonesia. In terms of the overall cost-benefit equation, even though patronage politics increases the cost of production for investors (since time and resources have to be spent in establishing and maintaining these relationships in order to get licenses or government permits to conduct investment) (Lipsey and Sjoholm, 2011: 43-44, Al-Sadig, 2009: 267), other country characteristics in Indonesia such as cheap labour and large markets make up for these negative costs (Lipsey and Sjoholm, 2011: 43-44). Furthermore, in the presence of rigid regulation and an inefficient bureaucracy such as in Indonesia, patronage politics may actually increase bureaucratic efficiency by speeding up the process of decision-making (Rose-Ackerman, 2008: 328-330, Al-Sadig, 2009: 269), and may in turn, indirectly encourage incoming investment and economic growth in Indonesia (Al-Sadig, 2009: 269, Richardson, 2010: 51), especially from neighbouring countries.

\section{Discussion: Patronage politics as a driver of haze}

Therefore, across the board in the Indonesian oil palm plantation sector, local, Malaysian and Singaporean plantation companies have individuals who have the ability to meet easily with 
ministries, Bupatis and governors to maintain patronage-type relationships (Surya [I9] and Akbar [I10], 2010, Syaf [I27], 2010, Arif [I41], 2011). Individuals are expected to appeal to the administration on the company's behalf should any problems arise (Arif [I41], 2011), and help to quietly 'settle' any disputes, including through informal influence with the local and central government (Interviewee M28, 2010, Arif [I41], 2011). Once the political connections were made, these companies faced few constraints from the local and central state framework (Johnston, 2005: 46). For example, when Rimbunan Hijau, a Malaysian forestry and oil palm company operating in Papua faced administrative troubles for clearing land outside their concessions, the company requested their staff Daniel Rolland to meet the local ministry to get all required documentation, which he was able to obtain, by virtue of his connections and native Papuan kinship bonds (Rolland [150], 2011). As a result, there is an extraordinary amount of support for oil palm expansion from higher-level local officials, largely due to the patronage links cultivated within the sector (Colfer, 2002: 314). Government agencies are thus 'captured' by industry interests (McCarthy and Zen, 2010: 155-171), 'not by gaining control over the policy making process and perverting it to its private benefit per se, but rather by tying the state's hands in ways that make it difficult for the state to effectively regulate business activity' in the sector (Wederman, 2002: 57).

Patronage influences in the sector are especially important in obtaining licenses and property rights for the opening of plantation land, one of the earliest stages involved in the process of establishing plantations. Influential actors in the sector are often able to obtain rights to environmentally sensitive land not normally released for conversion, like peatlands (Interviewee I49, 2011, Wibisino [I44], 2011). Indeed, one of the conditions for patronage politics to exist is that potential patrons must have access to instrumental, economic or political resources that can 
be tapped for patronage purposes (Hicken, 2011: 290-306). These resources are consciously allocated by patrons to particular clients who would otherwise not have received these gains (Nesadurai, 2004: 149-150). This is an important criterion of patronage relations, where privileges to property rights and licenses differ from 'free market' exchange, i.e. differ from outcomes strictly following the law (Eisenstadt and Roniger, 1995: 209-233).

Despite its infertility for other crops, peatlands are quite suitable for the growth of oil palm when deeply drained (Tan et al., 2009: 423). Opening up peatlands for plantations is also attractive to concessionaires because of the valuable timber growing in these areas. Another reason peatlands are highly attractive to concessionaires is because peatlands are usually free from Native Customary Rights claims, as communities rarely settle there. Therefore, acquiring peatlands is a good way to avoid highly publicized conflicts with increasingly vocal indigenous and local communities, which usually involve high compensation costs. However, peatland, when dried in preparation for planting, is extremely fire-prone (Wibisino [I44], 2011). Burning peat releases thick, sooty smoke that result in haze pollution (Tan et al., 2009: 423).

\section{Figure 5: Peat and palm oil in Indonesia, 2008}

The sensitive nature and ecological importance of peatlands justified special legislation under Presidential Decree Keppres No. 32/1990 and Indonesian Government Regulation No. 26/2008 restricting the planting of palm oil on peat more than three meters deep (Anshari [I42], 2011), but research has shown that, up to $25 \%$ of concessionaires, including local and foreign companies alike, deviate from this rule and plant on deep peat anyway (Silvius and Kaat, 2010: 21). All these plantation lands and future plantations on peat are essentially 'illegal' because it contravenes national laws (Interviewee I49, 2011). As a result, of the existing seven million 
hectares of palm oil concessions in Indonesia, approximately two million hectares, or $27 \%$ is located on peatlands (Silvius and Kaat, 2010: 13-23), and a further three million more have been licensed for conversion in the future (see Figure 5) (Suharto, 2010: 8). Furthermore, over 50\% of new palm oil plantation areas are planned in peatland areas (Greenpeace, 2007: 33). This amounts to an annual expansion of 150,000 to 200,000 hectares per year (Silvius and Kaat, 2010: 23).

Many major plantation companies have been found to have obtained licenses for peatlands in Riau. For example, Indonesian companies Duta Mas, Astra Agro and Musim Mas were all found to have acquired land on peat. Duta Palma was found to hold five concessions on very deep strata of peat ranging from 3.5 meters to eight meters, with a total area of 55,000 hectares. Musim Mas also has a concession on deep peat in Riau, with an estimated area of 30,600 hectares, in some areas over four meters deep. Astra Agro has two concessions on peatlands in Riau, with an estimated total area of 20,000 hectares. Foreign companies are no exception, like Singapore's GAR and Wilmar and Malaysia's KLK and THP. GAR has six concessions on peatlands in Riau, with an estimated total area of over 54,000 hectares. Wilmar has three concessions on peatlands in Riau, with an estimated total area of over 29,000 hectares (Greenpeace, 2007: 3-53). Indo Agri has a concession on peat in Riau, with an estimated total area of 8,500 hectares. 70\% (19,432 hectares) of PT API's (a subsidiary of KLK) land in Riau is on peatsoil (Saharjo et al., 2003: 3). And most of THP's 150,000 hectares of allocated plantation land in Riau is on peatsoil as well (Interviewee M28, 2010). In the neighbouring province of Jambi, companies like BSP, Sime Darby, Makin Group and GAR also operate on peatlands (Munadar et al., 2010: 1). 
Patronage relationships often also extend well beyond the licensing stage. A key criteria of patronage politics is the ongoing nature of the relationship, in contrast to one-off bribery (Hicken, 2011: 290-306). This is especially necessary with the Indonesian oil palm plantation sector. With oil palm, often plantation companies do not clear and plant the whole land parcel at once. They also constantly apply and receive approval for new land licenses in different areas. Furthermore, as mentioned above, crop rotation occurs every 20 to 30 years. This means that, land clearing for new plantings or replacement plantings often occur continually over time, not just once during the land lease. As discussed above, many plantation companies have used fire as a cost-efficient way to clear land (Chiew [M15], 2010, Then [M14], 2010, Nesadurai [M36], 2010), and these fires, especially when located on peatland, produce the smoke that cause transboundary haze. Therefore, long term patronage relationships have to be cultivated so that patron protection can be relied upon throughout this period of time (Surya [19] and Akbar [I10], 2010). Because of the long time frames of the sector and the continuous process of land clearing, it is important for companies to maintain ongoing patronage relationships to enable them to conduct unscrupulous land clearing with impunity (Surya [I9] and Akbar [I10], 2010, Syarif [I2], 2010), far beyond just the licensing stage.

Many Indonesian, Malaysian and Singaporean firms have been able to evade official investigation by the Indonesian government despite repeated indicators of open burning. For example, Indonesia's Duta Palma is known to be one of the companies with the worst track records in terms of illegal burning practices (Interviewee I47, 2011), but has never officially been scrutinized. Greenpeace investigations in Riau have revealed evidence of serious breaches of Indonesian law on Duta Palma plantations, especially illegal, intentional and systematic land clearing using fire. Since January 2006 to 2007, fires have been detected several times inside 12 
of Duta Palma concession areas. Planting of oil palm seeds often takes place immediately after burning, proving that the fires were deliberate (Greenpeace, 2007: 30-43). Similarly in West Kalimantan, the Rainforest Action Network (RAN) found evidence of burning on Duta Palma concessions in April 2009 (Laurance et al., 2010: 379, Gilbert, 2009: 2). According to the RAN report, 'foreboding clouds of black smoke hang over Semunying Jaya (the village), reminding the villagers that the clearing continues. After the chainsaws and bulldozers, Duta Palma labourers pour diesel fuel over the felled forest and sets it ablaze, lighting fires that smoulder for days' (Gilbert, 2009). Incidences of burning have been reported to various authorities by NGOs and village heads, but no legal action has resulted (Greenpeace, 2007: 2). As RAN argues, it is Duta Palma's connections within the Indonesian military that allows Duta Palma to operate with such impunity (Gilbert, 2009: 30-43).

Other similar cases were with plantations of Malaysian companies like THP and IOI. An interviewee from a Malaysian NGO, Global Environment Centre, explained that THP was known to have burned about 20,000 hectares of land in Sumatra in 1997, which was identified as being the main source of smoke travelling to Singapore that year (Interviewee M44, 2012: 2). More recently, following a report by Greenpeace who detected 234 hotspots on five of IOI's concession between 2006 and 2007 (Greenpeace, 2007: 21), Milieudefensie, another NGO, found that newly opened plantations in West Kalimantan belonging to Malaysia's IOI in 2009 had a substantial increase in fire hotspots in newly cleared land (Milieudefensie, 2010a: 12). It was found that prior to the start of land clearing activity in preparation for planting in 2009, there were no hotspots in the concession areas, however several concentrations of hotspots occurred in newly cleared areas. As the Milieudefensie report notes 'although the concentrated occurrence of fire hotspots in newly cleared plantation development areas alone does not represent hard 
evidence that IOI subsidiaries practice intentional open burning, few alternative causes could be determined' (Milieudefensie, 2010b: 18).

As mentioned above, plantations situated on peat are essentially 'illegal' because it contravenes national laws (Interviewee I49, 2011). And commercial land clearing by use of fire has been illegal in Indonesia since 1997 (Interviewee I6, 2010, Joedawinata [I33] and Sartono [I34], 2010, Udiansyah [I15], 2010, Keraf [I35], 2010, Tarigan [I23], 2010, Rowland [I39], 2011). However, this cultivation of patronage relations by both local and Malaysian and Singaporean companies therefore make it easy for these well-connected clients to skirt, resist, or even ignore state policies (Dauvergne, 1995: 89-98). Because of this, powerful businessmen with good patronage ties have no reason to fear punishment, and the law will be disregarded and wrong-doing may become the norm (Kurer, 1996: 645-661). In this way, corrupt patronage politics foster a culture of impunity and make it difficult to punish individuals for corrupt behavior. This creates a circle which leaves little hope in breaking the pattern of poor implementation. In this way, some state agencies end up accommodating, assisting or even strengthening the practices that destroy natural resources (Dauvergne, 1995: 89-98). As they are very hard to suppress, and as they serve the interests of their network members, they continue to flourish (Lande, 1983: 438-450). As one interviewee expressed, 'in such environments without the rule of law and with weak government institutions, the big and the powerful tend to have disproportionate influence' (Moore [I5], 2010).

Some of these patrons have been implicated by Indonesian law. For example, former governors of North Sumatra and Riau have been jailed because they were exposed for having 'unlawful connections' (vested interests) with oil palm companies (Syarif [I2], 2010, Yansen [I43], 2011). Indonesia Corruption Watch has identified and are currently investigating several Bupatis in 
West and Central Kalimantan that also have vested interests in plantations (Arif [I41], 2011). However, because patronage politics is so widespread that it is almost the norm (Dauvergne, 1995: 89-98), these cases are the minority. Even with anti-corruption efforts that intensified after the fall of President Suharto, recent reports indicate new setbacks, with the police force, the Parliament and the attorney general's office obstructing the work of the anti-corruption commission (Lipsey and Sjoholm, 2011: 55). For example, the Supreme Court has repeatedly annulled the regulation setting forth the creation of a joint investigating team to scrutinize complaints of patronage influence in the courts (Rajenthran, 2002: 50).

\section{Conclusion}

Therefore, through this close analysis of the business practices in the Indonesian oil palm plantation sector, several points become obvious. Firstly, because Malaysian and Singaporean firms are already familiar with patronage practices at home, Malaysian and Singaporean plantation investors were able to easily insert themselves into existing patronage networks in Indonesia (Tarigan [I23], 2010). This explains the intense economic regionalization of the Southeast Asian oil palm plantation sector, resulting in more than two-thirds of Indonesia's total oil palm plantation area being held by Malaysian and Singaporean interests (WALHI et al., 2009: 5).

Secondly, because of the ease in which Malaysian and Singaporean companies have been able to integrate into the Indonesian business environment, there are no discernible differences between the practices on the ground of local plantations companies and those of Malaysian and Singaporean investors. Local, Malaysian and Singaporean investors have been known to skirt regulations concerning land licensing and open burning, often inferring that political connections 
would protect them (Dauvergne, 1998: 13-17). This explains the recent evidence linking over $80 \%$ of haze-causing fires to plantation companies or their sub-contractors (Tan [S7], 2010, Rukmantara [I45], 2011). The rampant practice of patronage politics in this sector has enabled these local, Malaysian and Singaporean companies to act with impunity, even in the face of open burning allegations by civil society. Indeed, an NGO coalition known as the Anti-Plantation Mafia notes that patronage networks have been especially higher than average in the Indonesian palm oil plantation sector compared to other sectors in Indonesia because it involves a high level of illegal activity like illegal licensing and land clearing (Arif [I41], 2011). Therefore, patronage networks are especially important in this sector to protect these commercial interests (Syarif [I2], 2010, Arif [I41], 2011).

Thirdly, in a sector characterised by patronage politics such as the Indonesian oil palm plantation sector, both patrons and clients are exclusively motivated by material gain (Kurer, 1996: 645661). This explains why, despite Malaysia and Singapore being the worst victims of the transboundary haze, Malaysian and Singaporean firms continue to conduct their operations in the same way as do the Indonesian plantation companies, which include using fire to clear land for planting, in the interests of cost-efficiency. Furthermore, since many of these Malaysian and Singaporean companies are GLCs or otherwise linked to powerful political elite back home as well, these political elites are also somewhat motivated by material gain, and not the interests of the society suffering from haze. Therefore, transboundary haze is a classic collective action or free-rider problem: what might be rational at the level of society makes less sense at the level of the individual, and creates disincentives for people to go along with changes in patronage systems that would benefit the majority. Patrons disregard the long-term interest and focus on helping their clients; anyone outside the favoured group can expect little from the government. 
Hence, patrons are obligated to disregard the long-term interest of society for a haze-free atmosphere, focusing instead on helping their clients maximize profitability in the oil palm plantation sector (Larson and Soto, 2008: 218-226).

This paper has thus shown how the culture of patronage politics has been instrumental not only in driving the economic regionalization of the Southeast Asian oil palm plantation sector, but can also be linked to another regional-level issue, that of transboundary haze. In conclusion, it can be argued that the regionalization of the Southeast Asian oil palm plantation sector has been essentially bad for the environment and society of the region in the sense that it has been the cause of exacerbating transboundary haze. Differences of attitudes between Southeast Asian firms and these other foreign firms have been noted by several interviewees (Interviewee I48, 2012, Rolland [I50], 2012). As discussed above, while foreign firms that intend to enter into markets where patronage politics plays an important role will often attempt to engage in similar practices as well (Enderwick, 2005: 126, Hamilton-Hart, 2005: 171), these firms will usually continue to display distinctive local features of their home country in their business dealings in the new host country (Doremus et al., 1999). Hence, other foreign companies, like those from the Netherlands, Switzerland, and the United States that also operate in Indonesia, have generally not been able to fully integrate themselves into local patronage networks, a largely Asian characteristic (Enderwick, 2005: 129). Because of this, they do not have the liberty to act with impunity on the ground, and thus have only very rarely been linked to fire and other environmental misconducts in Indonesia (Interviewee I48, 2012, Rolland [I50], 2012). Therefore, it can be inferred that if there has not been such intense regionalization of the sector, there may not be such severe haze. In a situation where almost 'everyone is burning and the whole system operates based on burning' (Moore [I5], 2010), there is little hope to effectively 
address transboundary haze unless the root cause of the system, which this paper identifies as

patronage politics, is conclusively addressed.

\section{References}

AL-SADIG, A. 2009. The effects of corruption on FDI inflows. Cato Journal, 29.

ANSHARI [142], G. Z. 9 November 2011 2011. RE: Center for Wetlands People and Biodiversity, Universitas Tanjungpura.

ARIF [141], J. 4 November 2011 2011. RE: Forest Campaigner, Greenpeace Southeast Asia.

BAKRIE BROTHERS 2010. Annual Report. Indonesia: Bakrie Brothers.

BASIRON, Y. 2007. Palm oil production through sustainable plantations. European Journal of Lipid Science and Technology, 109, 289-295.

BEESON, M. 2004. Southeast Asia. In: PAYNE, A. (ed.) The New Regional Politics of Development. Hampshire: Palgrave Macmillan.

Author. 2010. Palm oil sector to become larger contributor to GDP. Bernama Daily Malaysian News, 30 March 2010.

BRESLIN, S. \& HIGGOTT, R. 2003. New regionalism(s) in the global political economy. Conceptual understanding in historical perspective. Asia Europe Journal, 1, 167-182.

BUTLER, R. A., LIAN, P. K. \& GHAZOUL, J. 2009. REDD in the red: Palm oil could undermine carbon payment scheme. Conservations Letters, 2, 67-73.

CARNEY, M. \& DIELEMAN, M. 2011. Indonesia's missing multinationals: Business groups and outward direct investment. Bulletin of Indonesian Economic Studies, 47, 105-26.

CASSON, A. 2002. The political economy of Indonesia's oil palm sector. In: COLFER, C. J. \& RESOSUDARMO, I. A. P. (eds.) Which Way Forward? People, forests and policymaking in Indonesia. Singapore: Institute of South East Asian Studies.

CHIEW [M15], H. 29 March 2010 2010. RE: former Environmental Reporter, The Star.

COLFER, C. J. P. 2002. Ten propositions to explain Kalimantan's fires. In: COLFER, C. J. \& RESOSUDARMO, I. A. P. (eds.) Which Way Forward? People, forests and policymaking in Indonesia. Singapore: Institute of Southeast Asian Studies.

Author. 2010. Interview Update 1 - Indonesia may cancel permits to save forests. Reuters, 18 August 2010.

DAUVERGNE, P. 1995. Shadows in the forest: Japan and the politics of timber in Southeast Asia. Doctor of Philosophy, University of British Columbia.

DAUVERGNE, P. 1997. Shadows in the Forest: Japan and the politics of timber in Southeast Asia, Cambridge, The MIT Press.

DAUVERGNE, P. 1998. The political economy of Indonesia's 1997 forest fires. Australian Journal of International Affairs, 52, 13-17.

DI, S. 2011. Tread Cautiously. Indo Plantations Sector Outlook. Jakarta: CLSA Asia Pacific Markets.

DIELEMAN, M. 2010. Shock-imprinting: External shocks and ethnic Chinese business groups in Indonesia. Asia pacific Journal of Management, 27, 481-502.

DIELEMAN, M. \& SACHS, W. 2006. Oscillating between a relationship-based and a market-based model: The Salim Group. Asia Pacific Journal of Management, 23, 521-536.

DIELEMAN, M. \& SACHS, W. 2008a. Reluctant internationalization: The case of the Salim Group. In: SURYADINATA, L. (ed.) Ethnic Chinese in contemporary Indonesia. Singapore: Institute for South East Asian Studies. 
DIELEMAN, M. \& SACHS, W. M. 2008b. Economies of connectedness: Concept and application. Journal of International Management, 14, 270-285.

DOREMUS, P. N., KELLER, W. W., PAYLY, L. W. \& REICH, S. 1999. The Myth of the Global Corporation, Princeton, Princeton University Press.

EISENSTADT, S. N. \& RONIGER, L. 1995. Patron-client relations as a model of structuring social exchange. In: EISENSTADT, S. N. (ed.) Power, Trust, and Meaning: Essays in Sociological Theory and Analysis. Chicago: The University of Chicago Press.

EKLOF, S. 2002. Politics, business, and democratization in Indonesia. In: GOMEZ, E. T. (ed.) Political business in East Asia. New York: Routledge.

ENDERWICK, P. 2005. What's bad about crony capitalism? Asian Business \& Management, 4, 117-132.

FAN, S., LIN, C. \& TREISMAN, D. 2009. Political decentralization and corruption: Evidence from around the world. Journal of Public Economics, 93, 14-34.

GENTING PLANTATIONS BERHAD 2010. Annual Report. Kuala Lumpur: Genting Plantations Berhad.

GHANI [S6], A. 17 May 2010 2010. RE: former Straits Times Press Reporter.

GILBERT, D. 2009. Duta Palma's filthy supply chain: A case study of a palm oil supplier in Indonesia. San Francisco: Rainforest Action Network.

GILL, P., STEWART, K., TREASURE, E. \& CHADWICK, B. 2008. Methods of Data Collection in Qualitative Research: Interviews and Focus Groups. British Dental Journal, 204.

GOLDEN AGRI-RESOURCES LTD 2010. Annual Report. Singapore: Golden Agri-Resources Ltd.

GOMEZ, E. T. 2009. The rise and fall of capital: Corporate Malaysia in historical perspective. Journal of Contemporary Asia, 39, 345-381.

GRANT, R. 2008. High hopes. Telegraph Magazine. London.

GREENPEACE 2007. How the palm oil industry is cooking the climate. Jakarta: Greenpeace.

GUNES-AYATA, A. 1994. Clientelism: Premodern, Modern, Postmodern. In: RONIGER, L. \& GUNESAYATA, A. (eds.) Democracy, Clientelism, and Civil Society. London: Lynne Rienner Publishers.

HAGGARD, S. \& LOW, L. 2002. State, politics, and business in Singapore. In: GOMEZ, E. T. (ed.) Political Business in East Asia. New York: Routledge.

HAJI MAT ZIN, R. 1999. Malaysian reverse investments: Trends and strategies. Asia Pacific Journal of Management, 16, 469-496.

HAMILTON-HART, N. 2005. The regionalization on Southeast Asian businesses: Transnational networks in national contexts. In: PEMPEL, T. J. (ed.) Remapping East Asia: The Construction of a Region. Ithaca: Cornell University Press.

HICKEN, A. 2011. Clientelism. Annual Review of Political Science, 14, 289-310.

HURRELL, A. 1995. Explaining the resurgence of regionalism in world politics. Review of International Studies, 21, 331-358.

INDO FOOD AGRI RESOURCES 2010. Annual Report. Singapore: Indo Food Agri Resources.

INDONESIAN GOVERNMENT 1998. Bahan informasi dalam rangka pertemuan working group for Sub Regional Fire Fighting Arrangement (ARA) di Singapura pada tanggal 6 Mei 1998. Pekanbaru: Department Kehutanan dan Perkebunan Kantor Wilayah Propinsi Riau.

INTERVIEWEE 16. 27 June 2010 2010. RE: formerly of Greenpeace-South East Asia.

INTERVIEWEE 147. 28 November 2011 2011. RE: Burung Indonesia.

INTERVIEWEE 148. 30 November 2011 2011. RE: Fauna Flora International.

INTERVIEWEE 149. 1 December 2011 2011. RE: Leuser Foundation.

INTERVIEWEE M28. 14 April 2010 2010. RE: TH Plantations.

INTERVIEWEE M44. 5 January 2012 2012. RE: Global Environment Center.

INTERVIEWEE M45, INTERVIEWEE M46, INTERVIEWEE M47 \& INTERVIEWEE M48. 17 January 20122012. RE: Plantation Sustainability Department, Sime Darby.

IOI GROUP 2011. Annual Report. Malaysia: IOI Group. 
ISTOCKANALYST. 2009. Indonesia's palm oil contributes 4.5 pct to GDP [Online]. Jakarta. Available: http://www.istockanalyst.com/article/viewiStockNews/articleid/3660667 [Accessed 6 October 2010].

Author. 1987. Indonesia's environment. Jakarta Post, 24 September 1987.

Author. 2006. Pests devastate Jambi harvests. Jakarta Post, 16 June 2006.

JARVIS, D., RICHMOND, N., PHUA, K. H., POCOCK, N., SOVACOOL, B. K. \& D'AGOSTINO, A. 2010. Palm oil in Southeast Asia. Asian Trends Monitoring Bulletin.

JOEDAWINATA [133], A. \& SARTONO [134]. 28 July 2010 2010. RE: Indonesian Palm Oil Commission.

JOHNSTON, M. 2005. Syndromes of Corruption: Wealth, Power and Democracy, New York, Cambridge University Press.

Author. 2010. Sinar Mas intends to regain image. Climate Action, 14 December 2010.

KERAF [135], S. 28 July 2010 2010. RE: former Minister of the Environment and Vice Chairman of Commission 7 (Environment, Energy and Research and Development), Parliament of Indonesia.

KUALA LUMPUR KEPONG BERHAD 2010. Annual Report. Ipoh: Kuala Lumpur Kepong Berhad.

KURER, O. 1996. The political foundations of economic development policies. Journal of Development Studies, 32, 645-668.

LANDE, C. H. 1983. Political clientelism in political studies: Retrospect and prospects. International Political Science Review, 4, 435-454.

LARSON, A. M. \& SOTO, F. 2008. Decentralization of natural resources governance regimes. Annual Review of Environment and Resources, 33, 213-239.

LAURANCE, W. F., KOH, L. P., BUTLER, R., SODHI, N. S., BRADSHAW, C. J. A., NEIDEL, J. D., CONSUNJI, H. \& VEGA, J. M. 2010. Improving the performance of the Roundtable on Sustainable Palm Oil for Nature Conservation. Conservation Biology, 24, 377-381.

LAWRENCE [138], P. 27 November 2011 2011. RE: Researcher, Ecostrategy.

LEE [S20], P. O. 26 May 2010 2010. RE: Fellow, Regional Economic Studies, Institute for South East Asian Studies.

LEW [M6], S. \& INTERVIEWEE M7. 18 March 2010 2010. RE: Peatland Programme, Global Environment Center.

LIPSEY, R. E. \& SJOHOLM, F. 2011. Foreign direct investment and growth in East Asia: Lessons for Indonesia. Bulletin of Indonesian Economic Studies, 47, 35-63.

MARINOVA, N. 1999. Indonesia's Fiery Crises. Journal of Environment \& Development, 8, 70-81.

MAYER, J. 2006. Transboundary Perspectives on Managing Indonesia's Fires. The Journal of Environment \& Development, 15, 202-233.

MCCARTHY, J. \& CRAMB, R. A. 2009. Policy narratives, landholder engagement, and oil palm expansion on the Malaysian and Indonesian frontiers. The Geographical Journal, 175, 112-123.

MCCARTHY, J. \& ZEN, Z. 2010. Regulating the oil palm boom: Assessing the effectiveness of environmental governance approaches to agro-industrial pollution in Indonesia. Law \& Policy, 32, 153-179.

MCCARTHY, J. F. 2010. Process of inclusion and adverse incorporation: oil palm and agrarian change in Sumatra, Indonesia. The Journal of Peasant Studies, 37, 821-850.

MILIEUDEFENSIE 2010a. Milieudefensie's Response to IOI's rebuttal in Substance. Jakarta: Milieudefensie.

MILIEUDEFENSIE 2010b. Too green to be true: IOI Corporation in Ketapang District, West Kalimantan. Amsterdam: Milieudefensie.

MOORE [15], P. F. 27 June 2010 2010. RE: Project Manager, IUCN-WWF Project Firefight Southeast Asia.

MUNADAR, A., RUTH, D. \& PUTRA, A. 2010. Rejection REDD Plus program Australia-Indonesia in Jambi. Position Paper. Jambi: Regional Executive WALHI Jambi. 
NAGUIB, R. \& SMUCKER, J. 2009. When economic growth rhymes with social development: The Malaysia experience. Journal of Business Ethics, 89, 99-113.

NESADURAI [M36], H. 28 April 2010 2010. RE: Senior Lecturer for International Studies, Monash University Sunday Campus.

NESADURAI, H. 2004. Asia-Pacfic approaches to regional governance: The globalization-domestic politics nexus. In: JAYASURIA, K. (ed.) Asian Regional Governance: Crisis and change. RoutledgeCurzon: New York.

NORHASHIM, M. \& AB. AZIZ, K. 2005. Smart partnership or cronyism? A Malaysian perspective. International Journal of Sociology and Social Policy, 25, 31-48.

PEMPEL, T. J. 2005. Introduction: Emerging webs of regional connectedness. In: PEMPEL, T. J. (ed.) Remapping East Asia: The construction of a region. Ithaca: Cornell University Press.

PETERS [I1], E. 13 April 2010 2010. RE: Sinarmas Group.

PRATONO, H. 2009. Indonesia oil palm plantation [Online]. Surabaya: Universitas Surabaya. Available: http://30205z.blogspot.com/2009 0401 archive.html [Accessed 9 August 2011].

RAHIM, L. Z. 2009. Singapore in the Malay World, New York, Routledge.

RAJENTHRAN, A. 2002. Indonesia: An overview of the legal framework of Foreign Direct Investment. ISEAS Working Papers: Economics and Finance. Singapore: Institute of Southeast Asian Studies.

RAMAKRISHNA [M20], S. 7 April 2010 2010. RE: Coordinator, Malaysian Environmental NGOs.

Author. 2011. Update 1 - Wilmar to invest $\$ 900 \mathrm{mln}$ in Indonesia palm oil product plants. Reuters, 7 February 2011.

RICHARDSON, C. L. Year. Deforestation due to palm oil plantations in Indonesia. In: Towards the Sustainable Production of Palm Oil, 2010 Australia.

ROLLAND [150], D. 7 December 2011 2011. RE: Former staff of Rimbunan Hijau.

ROSE-ACKERMAN, S. 2008. Corruption and government. International Peacekeeping, 15, 328-343.

ROWLAND [I39], I. 3 November 2011 2011. RE: Tropical Forest Conservation Manager, The Royal Society for the Protection of Birds.

RUKMANTARA [145], A. 14 November 2011 2011. RE: Former environmental journalist, Jakarta Post.

SAHARJO, B. H., DANNY, W., MOORE, P. F. \& SIMORANGKIR, D. 2003. Convicting forest and and fire offences: A case study of the legal process in Riau, Indonesia. Project Fire Fight. Jakarta.

SAMSUL, FIRMAN, MUHIB, SYARWANI, HELMI, NURDIN \& ZAKARIA 2007. The Golden Crop? Palm oil in post-tsunami Aceh. Aceh: Eye on Aceh.

SAWIT WATCH 2007. Palm oil for biofuels increases social conflicts and undermines land reform in Indonesia. Open letter to the European Parliament, the European Commission, the governments and citizens of the European Union. Bogor: SawitWatch.

SCOTT, J. C. 1972. Patron-Client Politics and Political Change in Southeast Asia. American Political Science Review, 66, 91-113.

SILVIUS, M. \& KAAT, A. 2010. Peat Swamp Forests and Palm Oil. Powerpoint Presentation. Indonesia.

SIM, A. B. 2006. Internationalization strategies of emerging Asian MNEs - Case study evidence on Singaporean and Malaysian firms. Asia Pacific Business Review, 12, 487-505.

SMART AGRIBUSINESS AND FOOD 2010. Annual Report. Jakarta: SMART Agribusiness and Food.

STOKES, D. \& BERGIN, S. 2006. Methodology or "methodolatry"? An Evaluation of Focus Group and Depth Interviews. Qualitative Market Research, 9.

SUHARTO, R. 2010. Challenges Faces by Indonesian Palm Oil. Yogyakarta: Indonesian Palm Oil Commission.

SUHARTO, R. 2011. Sustainable Palm Oil Development in Indonesia. Jakarta: Indonesia Palm Oil Commission.

SURYA [19], M. T. \& AKBAR [110], A. 30 June 2010 2010. RE: Deputy Directors, Wahana Lingkungan Hidup Indonesia. 
SYAF [127], R. 24 July 2010 2010. RE: Director of Conservation Information, Wahana Informasi.

SYARIF [I2], L. M. 24 June 2010 2010. RE: Chief, Cluster of Security and Justice Governance, Kemitraan Partnership.

SYARIF, L. M. \& WIBISANA, A. G. Year. Strengthening legal and policy frameworks for addressing climate change in Asia: Indonesia. In: Asian Environmental Compliance and Enforcement Network, 2007 United States. United States Environment Programme.

TAN [S7], A. K. J. 17 May 2010 2010. RE: Vice Dean, Faculty of Law, NUS.

TAN, A. K. J. 2004. Environmental laws and institutions in Southeast Asia: A review of recent developments. Singapore Year Book of International Law, 177-192.

TAN, K. T., LEE, K. T., MOHAMED, A. R. \& BHATIA, S. 2009. Palm oil: Addressing issues and towards sustainable development. Renewable and Sustainable Energy Reviews, 13, 420-427.

TARIGAN [123], A. 16 July 2010 2010. RE: Executive Director, Sawit Watch.

TAY, S. 2003. Corruption after the crisis: Governance, Asian values, and international instruments. In: TAY, S. S. C. \& SEDA, M. (eds.) The enemy within: Combating corruption in Asia. Singapore: Eastern University Press.

TERJESEN, S. \& ELAM, A. 2009. Transnational entrepreneurs' venture internationalization strategies: A practice theory approach. Entrepreneurship Theory and Practice, 1093-1116.

TH PLANTATIONS 2010. Annual Report. Kuala Lumpur: TH Plantations.

THEN [M14], S. 28 March 2010 2010. RE: Environmental Reporter, The Star.

UDIANSYAH [115]. 28 July 2010 2010. RE: Faculty of Forestry, Lambung Mangkurat University.

UOB KAY HIAN 2011. Plantation Sector: Peak production growth is over; upgrade to market weight. Change of Recommendation. Regional. Kuala Lumpur: Regional Research Team, UOB Kay Hian.

VAN GELDER, J. W. 2004. Greasy palms: European buyers of Indonesian palm oil. Castricum: Friends of the Earth.

WAHID, M. B., ABDULLAH, S. N. A. \& HENSON, I. E. 2004. Oil palm - Achievements and potential. "New directions for a diverse planet" Proceedings of the 4th International Crop Science Congress. Brisbane.

WALHI, SAWIT WATCH \& CELCOR 2009. Malaysian Palm Oil and Logging Investments and Operations. Factsheet.

WEDERMAN, A. 2002. Development and corruption: The East Asian paradox. In: GOMEZ, E. T. (ed.) Political Business in East Asia. New York: Routledge.

WIBISINO [144], I. T. C. 10 November 2011 2011. RE: Wetlands International.

WIDIANARKO, B. Year. Democratization, Decentralisation and Environmental Conservation in Indonesia. In: Asia-pacific NGO Environmental Conference, 2009 Kyoto.

WILMAR 2010. Annual Report. Singapore: Wilmar.

WIRYONO [140]. 8 November 2011 2011. RE: Forestry Department, University of Bengkulu.

WORLD GROWTH 2011. The economic benefit of palm oil to Indonesia. Virginia: World Growth.

YANSEN [143]. 9 November 2011 2011. RE: Tropical Ecologist, University of Bengkulu. 
Figure 1: Area harvested of oil palm fruit in Indonesia, 1961-2009

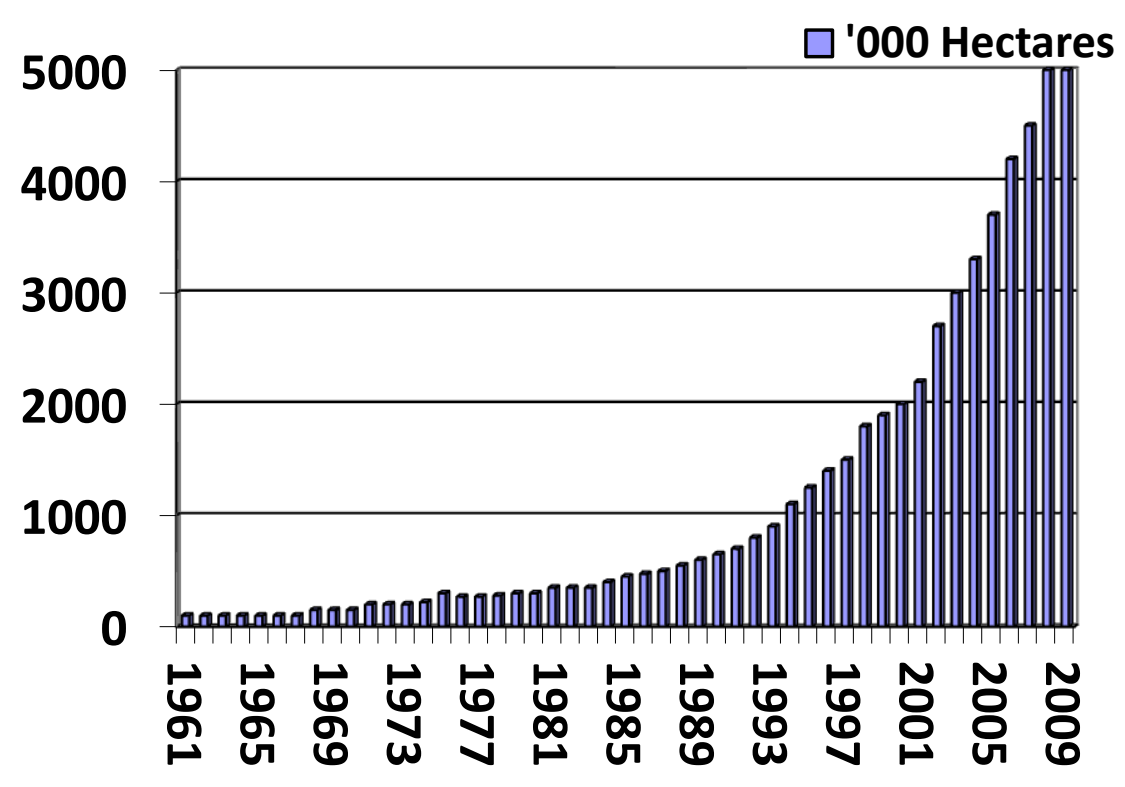

Source: FAOSTAT, 2009 
Figure 2: CPO production by country

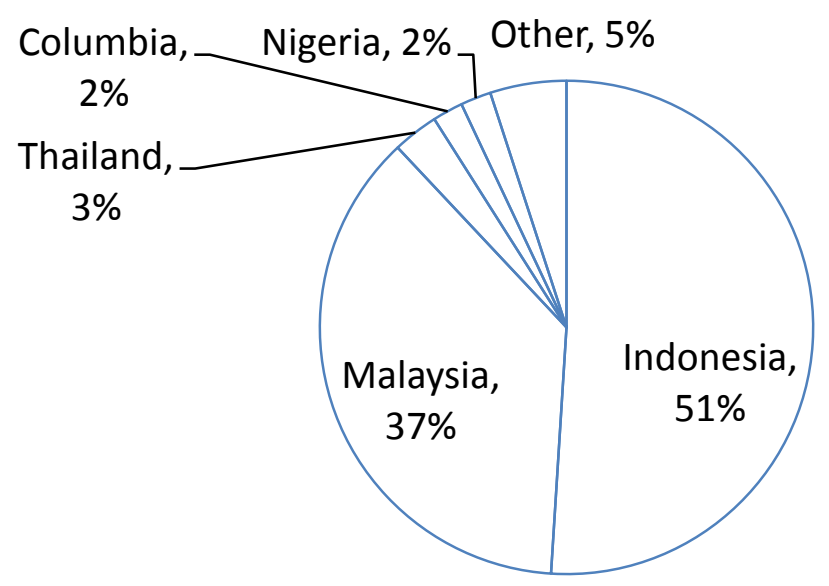

Source: Di, 2011: 3 
Figure 3: Breakdown of Indonesia's 2010 GDP by sector

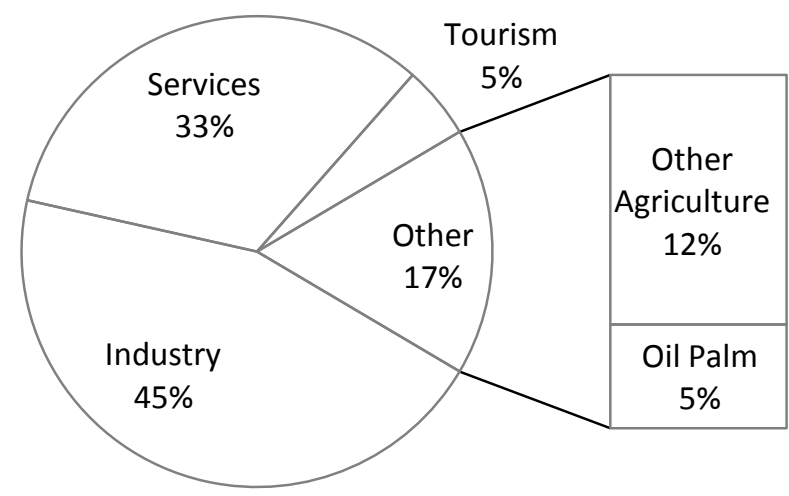

Adapted from: Rosendar, 2001, iStockAnalyst, 2009 
Figure 4: Country of origin of investors in the oil palm sector in Indonesia, 2004

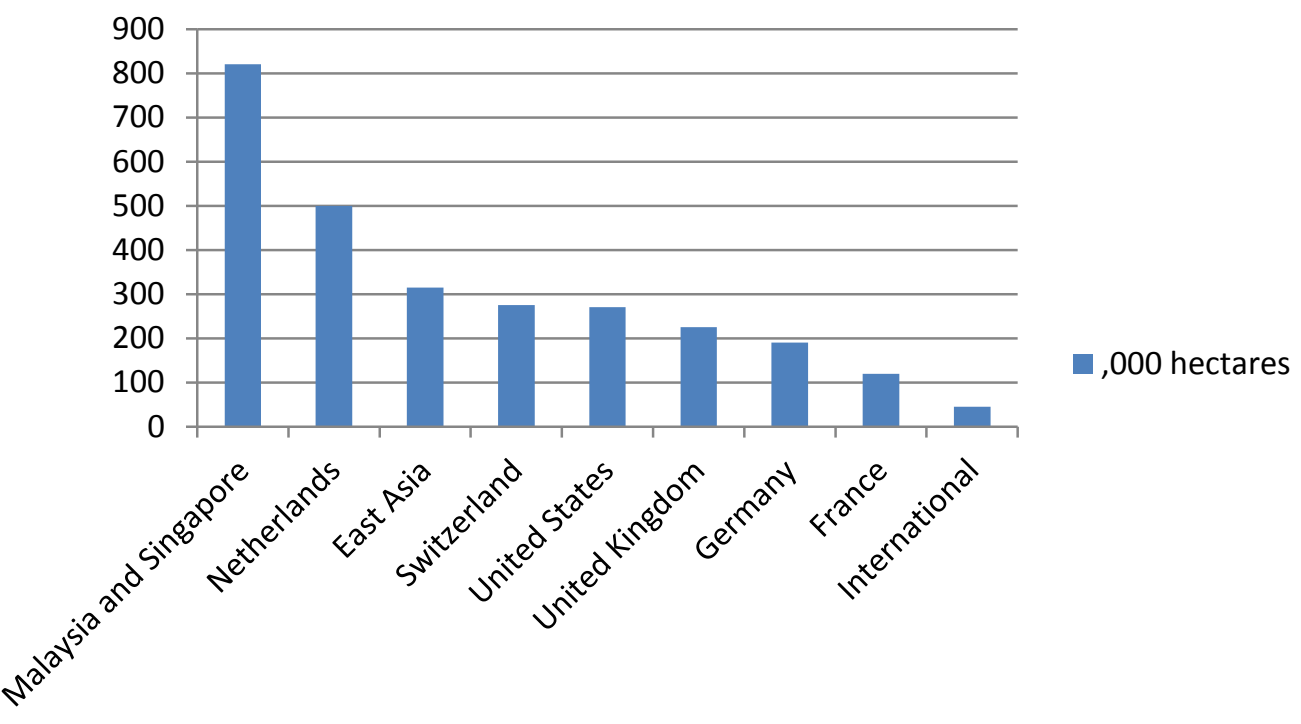

Source: WALHI and Sawit Watch, 2009 
Figure 5: Peat and palm oil in Indonesia, 2008

\begin{tabular}{|l|c|}
\hline \multicolumn{1}{|c|}{ Indonesia } & Hectares \\
\hline Land area & $190,000,000$ \\
\hline Area consisting of peat & $26,500,000$ \\
\hline Area of which is degrading & $12,500,000$ \\
\hline Area licensed for conversion into oil palm & $5,000,000$ \\
\hline Area converted to oil palm & $2,000,000$ \\
\hline \% of palm oil (present and future) on peat & $27 \%$ \\
\hline
\end{tabular}

Adapted from: Silvius and Kaat, 2010: 16, Kaat and Silvius, 2011: 5, Suharto, 2010: 8 